\title{
Field Level Investigation of Automated Drip Irrigation System
}

\author{
K.V. Arjun Prakash ${ }^{1 *}$, S. Sajeena ${ }^{2}$ and S.V. Lakshminarayana ${ }^{1}$ \\ ${ }^{1}$ Kerala Agricultural University, Kerala, India \\ ${ }^{2} \mathrm{KVK}$, Malappuram, KAU, India \\ *Corresponding author
}

\begin{abstract}
A B S T R A C T
Keywords

Capacitance, Drip irrigation, Electrical conductivity,

Fertigation, GSM modem, Sensors and Solenoid valve.

Article Info

Accepted:

15 March 2017

Available Online:

10 April 2017

Water is the most valuable resource in the world and is playing a crucial role in daily activities of living beings on the earth. To meet the ever increasing demand, conservation and management of water resource is very important. Conventional methods of irrigation, like surface and subsurface flooding leads to scarcity of water, which can be reduced by adopting drip or trickle irrigation. Drip irrigation system can be controlled through different automation techniques. Field study was carried out with Hilton FI variety of salad cucumber under different irrigation and fertigation levels using solenoid valves and GSM modem technique. The automated drip irrigation system consists of two capacitor type and two conductive type soil moisture sensors, solenoid valves and water flow sensors. Total yield and crop growth parameters showed better performance under 100 per cent fertigation when compared with 70 per cent fertigation. Combination of 100 per cent fertigation with 70 per cent irrigation also showed good results, whereas production was less in the case of 70 per cent fertigation with 70 per cent irrigation. The modified automated drip irrigation system is cost effective, portable and durable and it shows better performance.
\end{abstract}

\section{Introduction}

Water is the most valuable resource in the world and it is essential for all the forms of lives on the earth. Human beings need around 120 litres of water for their daily activities. Water usage without proper planning, depletes the water level in dams, reservoirs and other water sources. During $21^{\text {st }}$ century water has become the scarcest commodity in the world due to the ever increasing demand and over exploitation. According to UN, more than 200 crore people are troubled because of water shortage. All over the world, during next two decades, usage of water will increase by 25 per cent, resulting in doubling the scarcity. In India per capita water availability was around 6042 cubic meters at the time of independence from 1000 bore holes and this availability got reduced in an alarming rate year by year. In 2016, per capita availability is about 1500 cubic meters and if this situation continues, it may further reduce to 1,300 cubic meters by 2025 . State of Kerala though receives an average annual rainfall of $3000 \mathrm{~mm}$ and 44 rivers flowing across the land, due to the uneven and unplanned use of water, people are facing water scarcity during summer season.

The simple surface irrigation technique causes seepage losses, erosion, water logging 
problems, deep percolation, salinization and runoff. For getting satisfactory growth, two aspects to be considered are exact amount of water supply allowing exact delivery control and uniform water application in the field. These needs can be accomplished only by using micro irrigation techniques. The drip or trickle systems works with low pressure and it apply water more precisely to the plants. Micro irrigation systems are widely used for high value horticultural and nursery crops and this technique contributed more accuracy in reducing the water requirement of agricultural and horticultural crops. The water loss in irrigated agriculture occurs through percolation and evaporation. In the case of micro irrigation the water loss due to percolation and evaporation is very less, so the water use efficiency of the crop becomes increased.

During past two decades, many experiments have been conducted at various levels for the design as well evaluation of automated drip irrigation system. In India the concept of water management by automated irrigation is relatively newer which is getting stabilized slowly. Automated drip management refers to those innovations which fully or partially replace manual incorporation in watering operations. Automated drip irrigation includes automation at farm level or regional level coding with the soil type and characteristics.

\section{Materials and Methods}

\section{Study area}

The experiment was conducted in the polyhouse located in the instructional farm of KCAET Tavanur, Malappuram district located at $10^{\circ} 51^{\prime} 5^{\prime \prime}$ North Latitude and $75^{\circ}$ 59'14" East Longitudes. Climate of the study area is humid tropical with an average annual rainfall of $3000 \mathrm{~mm}$, mainly from South-West and North-East monsoon.

\section{Drip automation system}

The system is developed using electronic equipment so that it regulates the flow of water through the laterals and provide adequate quantity of water to each plant on time. The system is combined with microcontroller, which collects the reading from the capacitor type and conductive type sensors and the data are stored in the space allocated in the microcontroller. The system contains sim900 GSM modem used for sending and receiving output data and input commands respectively. A macro SIM is inserted in to the modem for the operation of the drip irrigation system. A water flow sensor was used to check the amount of water used for irrigating the entire plot. The system connected to the drip lateral has less weight, portable and is water resistant. All measurements can be done rapidly because the calibration of system is dependent upon response time and soil types.

\section{Field and crop condition}

The location of the experiment lies in the border of central zone and north zone of Kerala and near to the Bharathapuzha River. The region gets rainfall mainly from the contribution of south west monsoon. The total area of the poly house is $292 \mathrm{~m}^{2}$ in which the drip irrigation was done with four beds with single row plantation. The land preparation was done before the installation of the system in the field. Salad cucumber (Cucumis sativas L.) variety Hilton FI was used for the field experiment. The crop has 90 days duration and it is good variety with high productivity and growth in the lateritic soil under polyhouse cultivation.

\section{Crop water requirement}

The drip irrigation in poly house was controlled using the different parameters and 
it can be calculated with different approaches. The crop water requirement was calculated by irrigation scheduling method (Jadhav et al., 2002).

$\mathrm{WR}=\mathrm{E}_{\mathrm{pan}} \mathrm{x} \mathrm{K}_{\mathrm{p}} \times \mathrm{K}_{\mathrm{c}} \times \mathrm{W}_{\mathrm{p}} \times \mathrm{A}$

\section{Field layout}

The field for cultivation of salad cucumber using automatic drip irrigation was prepared inside the polyhouse of PFDC, Tavanur. The plot was arranged as four beds having $30 \mathrm{~cm}$ length and $1 \mathrm{~m}$ width and plastic mulching was laid out to reduce weeds. Water source for the irrigation was supplied through $60 \mathrm{~mm}$ diameter PVC pipe and it moves through sub mains of $40 \mathrm{~mm}$. The entire water irrigates the bed through $16 \mathrm{~mm}$ lateral lines made up of LDPE pipes arranged centerline of each bed. The water was pumped from "well" located $90 \mathrm{~m}$ away from the poly house using $3 \mathrm{hp}$ three phase motor. Seedlings were planted on the centerline of the bed and the lateral line having $35 \mathrm{~m}$ length with 21 emitters having 4 lph capacities were laid out. Figure 1 shows the field layout of the experiment.

The plot inside the poly house was ploughed thoroughly using manual tools and the field was leveled for making ridges and furrows. Fumigants were applied to the prepared bed before planting for controlling soil-borne diseases and weeds. Basal dose of fertilizer was applied to the soil bed. The beds were prepared with a top width of $90 \mathrm{~cm}$, height 40 $\mathrm{cm}$, and bottom width $100 \mathrm{~cm}$ and laterals were laid on it. The four sensors were inserted in to the beds and drip irrigation system was installed. Salad cucumber seeds were sown in plastic trays and seedlings were planted in to each bed to reduce virus attack. Foggers were provided for giving cooling when the inside temperature is high. The arrangement of plot is shown in figure 2 .
Seedlings were transplanted and irrigation was given to each bed through emitters using automated drip system. Seedlings were planted $1.5 \mathrm{~m}$ apart on each bed and drippers were fitted near to each plant. Irrigation was given in accordance with the treatment. Four treatments were used,

- T1-100percent fertigation and 100percent irrigation

- T2-100percent fertigation and 70percent irrigation

- T3-70percent fertigation and 70percent irrigation

- T4-70percent fertigation and 100percent irrigation.

Figure 3 shows the treatment and replication of the experiment.

The upper and lower limits of the sensor were set to identify the level of the water in each bed separately. The motor was ON/OFF by messaging corresponding to the difference in limits. The solenoid valves were operated according to the moisture level in the bed. When the moisture content came to lower limit then the motor was ON by message and water flows through the emitters via solenoid valve with the lighting of LED. When the moisture content reaches upper limit motor gets OFF by another message and the flow stops.

Recommended fertilizers for Hilton FI variety of salad cucumber were supplied every three day interval. Mono-ammonium phosphate (12:61:0), 19:19:19, Potassium Nitrate (13:0:45) and urea were used as the source of NPK. Fertigation treatments in each bed are given in table 1 .

\section{Results and Discussions}

Field study of automated drip irrigation system was conducted in the polyhouse using 
Hilton FI variety of salad cucumber. Results of the calibration of sensors and field evaluation are discussed in detailed in this chapter.

\section{Performance evaluation of drip automation system}

The system is very economical and portable when compared with other automation systems. Capacitor type sensor showed high linearity between capacitance and moisture content, while conductive type sensor showed less linearity between EC and soil moisture content. Both types of sensors are highly sensitive and light weight. The conductive type sensor electrodes may get corroded slightly while operating in the field condition, whereas capacitor type sensors are made with Teflon coating, hence it is durable than conductive type. The sensors and valves can be operated easily and installation of system is easy. There is scope for further modification of shape and precision of sensors.

When the system is switched ON, the present status of EC value and capacitance value of soil sensed by sensors and the status of motor are sent from the GSM modem to the mobile phone of user (which was already fed into the
GSM modem). Solenoid valves of each bed are also controlled by the direction of users as messages like $\mathrm{CO} 1 \mathrm{ON}, \mathrm{CO} 2 \mathrm{ON}, \mathrm{CA} 1 \mathrm{ON}$ and CA2 ON etc to the modem. System shuts down by the OFF message. The display of status and messaging setup in the mobile phone are shown in figure 4.

\section{Field evaluation of automated drip system}

Automated drip system was placed in front of the beds and sensors were fixed to each bed (total 4 sensor and 4 beds) as shown in figure 5 .

Soil moisture sensors in each bed sense the moisture content in terms of electrical conductivity and capacitance and are transferred to microcontroller unit. This data are processed by MCU as per the lower limit and upper limit value fed on it. The lower limit and upper limit value of capacitance and EC were calculated with moisture content at wilting point and field capacity respectively (on the basis of calibration curves). In this study the soil type is laterite and the moisture content corresponding to wilting point and field capacity of laterite soil are 10 to $15 \%$ and 35 to $45 \%$ respectively.

Table.1 Fertigation treatments

\begin{tabular}{|c|c|c|c|c|c|}
\hline $\begin{array}{c}\text { Days of } \\
\text { fertigation }\end{array}$ & $\begin{array}{c}\text { Water soluble } \\
\text { Fertilizer }\end{array}$ & $\begin{array}{c}\text { T1-100\% } \\
\text { fertigation } \\
(\mathrm{Kg})\end{array}$ & $\begin{array}{c}\text { T2-100\% } \\
\text { fertigation } \\
(\mathrm{Kg})\end{array}$ & $\begin{array}{c}\text { T3-70\% } \\
\text { fertigation } \\
(\mathrm{Kg})\end{array}$ & $\begin{array}{c}\text { T4- 70\% } \\
\text { fertigation } \\
(\mathrm{Kg})\end{array}$ \\
\hline & Basal dose P & 0.456 & 0.456 & 0.080 & 0.080 \\
\hline $3-18$ & $19: 19: 19$ & 0.080 & 0.080 & 0.014 & 0.014 \\
\hline & $13: 00: 45$ & 0.069 & 0.069 & 0.012 & 0.012 \\
\hline & Urea & 0.062 & 0.062 & 0.011 & 0.011 \\
\hline & $12: 61: 00$ & 0.002 & 0.002 & 0.000 & 0.000 \\
\hline & $19: 19: 19$ & 0.040 & 0.040 & 0.007 & 0.007 \\
\hline & $13: 00: 45$ & 0.146 & 0.146 & 0.026 & 0.026 \\
\hline & Urea & 0.026 & 0.026 & 0.004 & 0.004 \\
\hline & $12: 61: 00$ & 0.015 & 0.015 & 0.003 & 0.003 \\
\hline
\end{tabular}


Table.2 Plant height during the plant growth period

\begin{tabular}{|c|c|c|c|c|c|c|}
\hline \multirow{2}{*}{ Treatment } & \multicolumn{7}{|c|}{ Plant height $(\mathbf{c m})$} \\
\cline { 2 - 7 } & 14DAP & 21DAP & 28DAP & 35DAP & 42DAP & 49DAP \\
\hline T1 & 45.71 & 141.44 & 199.71 & 234.13 & 284.63 & 330.66 \\
\hline T2 & 56.57 & 168.98 & 218.07 & 250.18 & 300.86 & 342.71 \\
\hline T3 & 60.31 & 170.71 & 220.28 & 244.85 & 283.25 & 315.35 \\
\hline T4 & 58.89 & 172.66 & 226.90 & 253.86 & 281.20 & 308.26 \\
\hline
\end{tabular}

Table.3 Number of leaves during the plant growth period

\begin{tabular}{|c|c|c|c|c|c|c|}
\hline \multirow{2}{*}{ Treatment } & \multicolumn{7}{|c|}{ Number of leaves } \\
\cline { 2 - 7 } & 14DAP & 21DAP & 28DAP & 35DAP & 42DAP & 49DAP \\
\hline T1 & 9 & 19 & 33 & 49 & 65 & 84 \\
\hline T2 & 10 & 24 & 36 & 44 & 56 & 75 \\
\hline T3 & 11 & 29 & 35 & 40 & 46 & 60 \\
\hline T4 & 10 & 28 & 45 & 43 & 55 & 65 \\
\hline
\end{tabular}

Table.4 Number of flowers during the plant growth period

\begin{tabular}{|c|c|c|c|c|c|c|}
\hline \multirow{2}{*}{ Treatment } & \multicolumn{7}{|c|}{ Number of flowers } \\
\cline { 2 - 7 } & 14DAP & 21DAP & 28DAP & 35DAP & 42DAP & 49DAP \\
\hline T1 & 0 & 0 & 1 & 6 & 9 & 11 \\
\hline T2 & 0 & 0 & 2 & 10 & 11 & 12 \\
\hline T3 & 0 & 1 & 3 & 7 & 8 & 10 \\
\hline T4 & 0 & 2 & 4 & 11 & 13 & 15 \\
\hline
\end{tabular}

Table.5 Stem girth during the plant growth period

\begin{tabular}{|c|c|c|c|c|c|c|}
\hline \multirow{2}{*}{ Treatment } & \multicolumn{7}{|c|}{ Stem girth $(\mathbf{c m})$} \\
\cline { 2 - 7 } & 21DAP & 28DAP & 35DAP & 42DAP & 49DAP & 56 DAP \\
\hline T1 & 1.89 & 2.31 & 2.66 & 2.90 & 3.24 & 3.59 \\
\hline T2 & 2.29 & 2.59 & 2.86 & 3.07 & 2.99 & 3.31 \\
\hline T3 & 2.42 & 2.51 & 2.65 & 2.84 & 2.55 & 2.15 \\
\hline T4 & 2.27 & 2.51 & 2.61 & 2.8 & 3.00 & 3.09 \\
\hline
\end{tabular}


Table.6 Growth parameters of salad cucumber plant (last observation)

\begin{tabular}{|c|c|c|c|c|c|}
\hline \multicolumn{2}{|c|}{ Treatment } & Plant height & Number of & Number of & Stem girth $(\mathrm{cm})$ \\
\hline \multirow{6}{*}{ T1 } & $\mathrm{R} 1$ & 335.66 & 85 & 13 & 3.5 \\
\hline & R2 & 340.00 & 84 & 9 & 3.7 \\
\hline & R3 & 370.00 & 104 & 16 & 3.6 \\
\hline & $\mathrm{R} 4$ & 374.00 & 106 & 15 & 3.8 \\
\hline & R5 & 313.33 & 81 & 11 & 3.5 \\
\hline & R6 & 316.66 & 84 & 6 & 3.2 \\
\hline & R7 & 265.00 & 55 & 8 & 3.6 \\
\hline \multirow{7}{*}{$\mathbf{T} 2$} & R1 & 296.66 & 46 & 8 & 2.3 \\
\hline & R2 & 378.33 & 76 & 16 & 4.0 \\
\hline & R3 & 370.66 & 73 & 15 & 4.0 \\
\hline & $\mathrm{R} 4$ & 366.66 & 83 & 10 & 3.8 \\
\hline & R5 & 366.66 & 85 & 15 & 3.9 \\
\hline & R6 & 320.00 & 88 & 10 & 3.8 \\
\hline & R7 & 300.00 & 75 & 13 & 3.7 \\
\hline \multirow{7}{*}{ T3 } & R1 & 353.33 & 85 & 14 & 4.1 \\
\hline & R2 & 228.33 & 47 & 6 & 3.2 \\
\hline & R3 & 290.00 & 56 & 10 & 3.7 \\
\hline & $\mathrm{R} 4$ & 340.00 & 23 & 2 & 4.1 \\
\hline & R5 & 325.00 & 44 & 4 & 3.4 \\
\hline & R6 & 338.33 & 78 & 14 & 3.4 \\
\hline & R7 & 332.50 & 83 & 16 & 3.8 \\
\hline \multirow{7}{*}{ T4 } & R1 & 315.00 & 68 & 12 & 3.3 \\
\hline & R2 & 303.33 & 61 & 14 & 3.6 \\
\hline & R3 & 300.33 & 60 & 16 & 3.6 \\
\hline & $\mathrm{R} 4$ & 323.33 & 66 & 20 & 3.8 \\
\hline & R5 & 293.33 & 67 & 10 & 3.4 \\
\hline & R6 & 280.00 & 39 & 12 & 3.1 \\
\hline & R7 & 342.5 & 87 & 23 & 3.7 \\
\hline
\end{tabular}


Table.7 Yield parameters of salad cucumber plant (last observation)

\begin{tabular}{|c|c|c|c|c|c|}
\hline \multicolumn{2}{|c|}{ Treatment } & \multirow{2}{*}{$\begin{array}{c}\begin{array}{c}\text { Number of } \\
\text { fruits }\end{array} \\
16 \\
\end{array}$} & \multirow{2}{*}{$\begin{array}{c}\text { Fruit length } \\
\qquad \begin{array}{c}\text { (cm) } \\
\\
17.5 \\
\end{array}\end{array}$} & \multirow{2}{*}{$\begin{array}{c}\begin{array}{c}\text { Fruit } \\
\text { circumference } \\
(\mathbf{c m})\end{array} \\
13.1 \\
\end{array}$} & \multirow{2}{*}{$\begin{array}{c}\begin{array}{c}\text { Fruit } \\
\text { weight }(\mathbf{k g})\end{array} \\
0.158 \\
\end{array}$} \\
\hline \multirow{7}{*}{ T1 } & R1 & & & & \\
\hline & $\mathrm{R} 2$ & 14 & 16.7 & 11.4 & 0.127 \\
\hline & R3 & 12 & 16.7 & 12.0 & 0.132 \\
\hline & $\mathrm{R} 4$ & 15 & 21.1 & 14.8 & 0.243 \\
\hline & R5 & 10 & 13.1 & 10.7 & 0.069 \\
\hline & R6 & 11 & 17.0 & 12.2 & 0.136 \\
\hline & R7 & 9 & 17.5 & 13.1 & 0.158 \\
\hline \multirow{7}{*}{$\mathbf{T} 2$} & R1 & 17 & 17.6 & 13.1 & 0.165 \\
\hline & $\mathrm{R} 2$ & 14 & 17.5 & 13.0 & 0.163 \\
\hline & R3 & 12 & 18.2 & 14.0 & 0.202 \\
\hline & $\mathrm{R} 4$ & 11 & 20.8 & 14.6 & 0.261 \\
\hline & R5 & 14 & 18.0 & 13.0 & 0.155 \\
\hline & R6 & 14 & 17.8 & 13.3 & 0.167 \\
\hline & R7 & 11 & 15.2 & 13.1 & 0.106 \\
\hline \multirow{7}{*}{ T3 } & $\mathrm{R} 1$ & 12 & 15.7 & 12.8 & 0.132 \\
\hline & $\mathrm{R} 2$ & 9 & 16.0 & 12.6 & 0.139 \\
\hline & R3 & 9 & 16.3 & 14.0 & 0.164 \\
\hline & $\mathrm{R} 4$ & 8 & 15.7 & 14.7 & 0.210 \\
\hline & R5 & 11 & 16.2 & 12.8 & 0.165 \\
\hline & R6 & 7 & 15.9 & 13.1 & 0.161 \\
\hline & R7 & 8 & 16.9 & 12.5 & 0.137 \\
\hline \multirow{7}{*}{ T4 } & $\mathrm{R} 1$ & 12 & 12.8 & 12.5 & 0.115 \\
\hline & $\mathrm{R} 2$ & 8 & 16.5 & 13.7 & 0.182 \\
\hline & R3 & 11 & 15.5 & 14 & 0.160 \\
\hline & $\mathrm{R} 4$ & 9 & 17.7 & 14.5 & 0.208 \\
\hline & R5 & 11 & 16.2 & 11.0 & 0.120 \\
\hline & R6 & 10 & 16.3 & 11.6 & 0.130 \\
\hline & $\mathrm{R} 7$ & 9 & 18.3 & 14.2 & 0.175 \\
\hline
\end{tabular}


Fig.1 Field layout with drip lateral

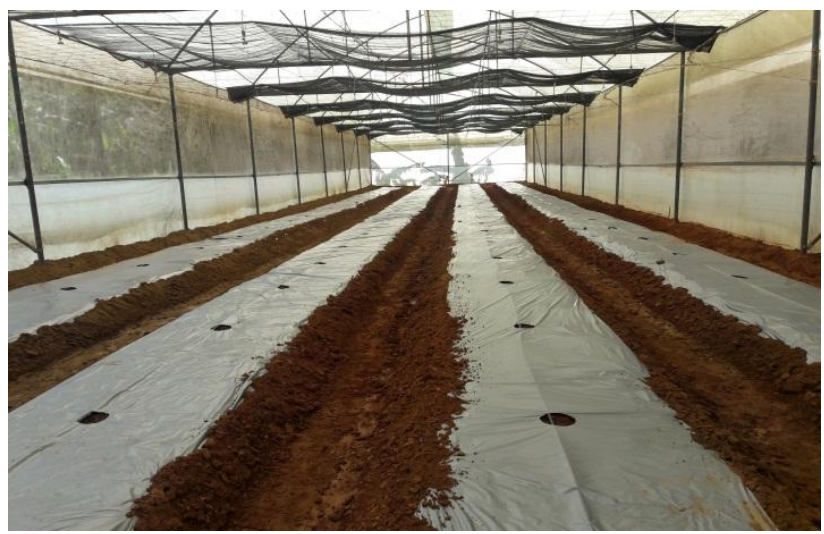

Fig.2 Planted condition of salad cucumber

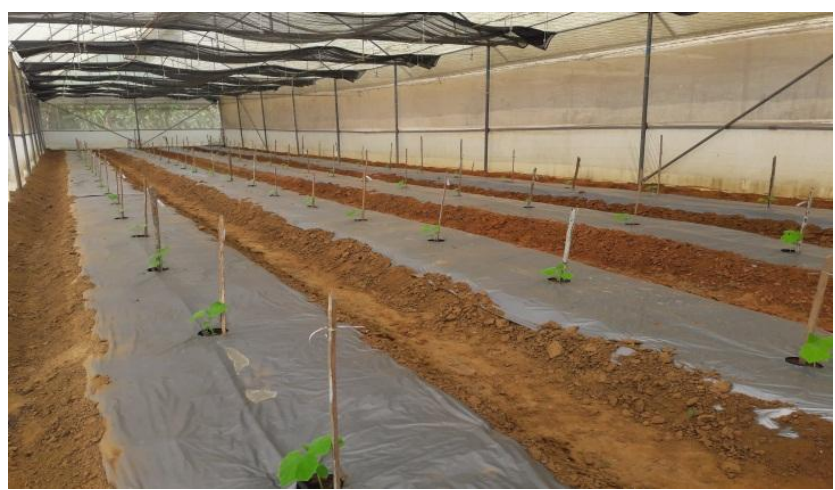

Fig.3 Field layout

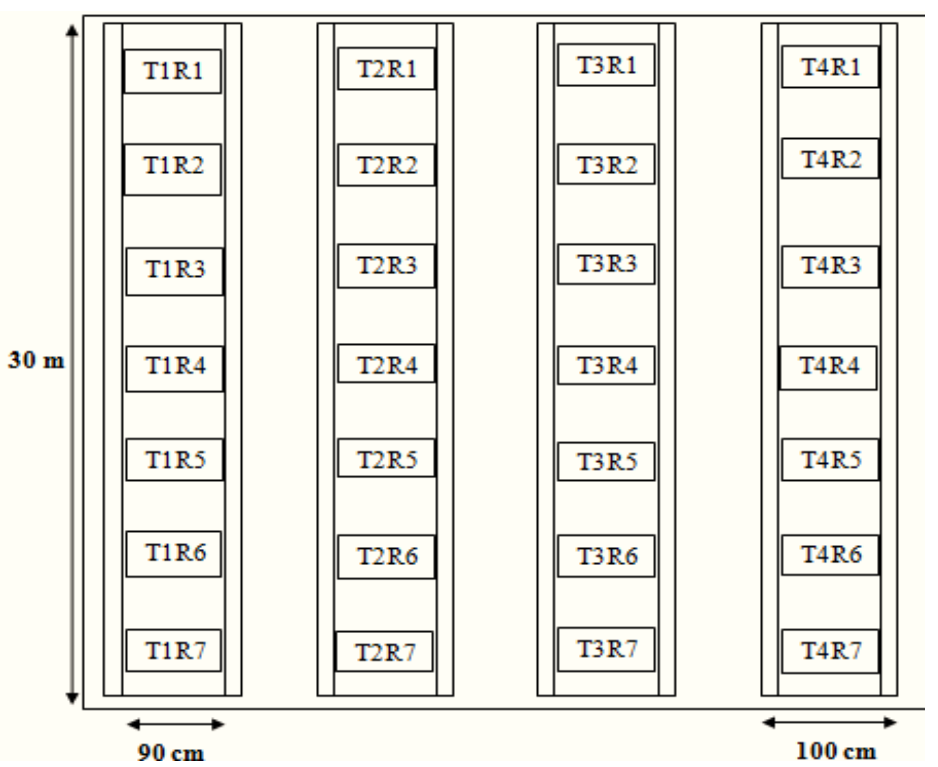


Fig.4 Status messages to the system

Project
P919501530637

Fig.5 Evaluation of conductive and capacitor type sensor

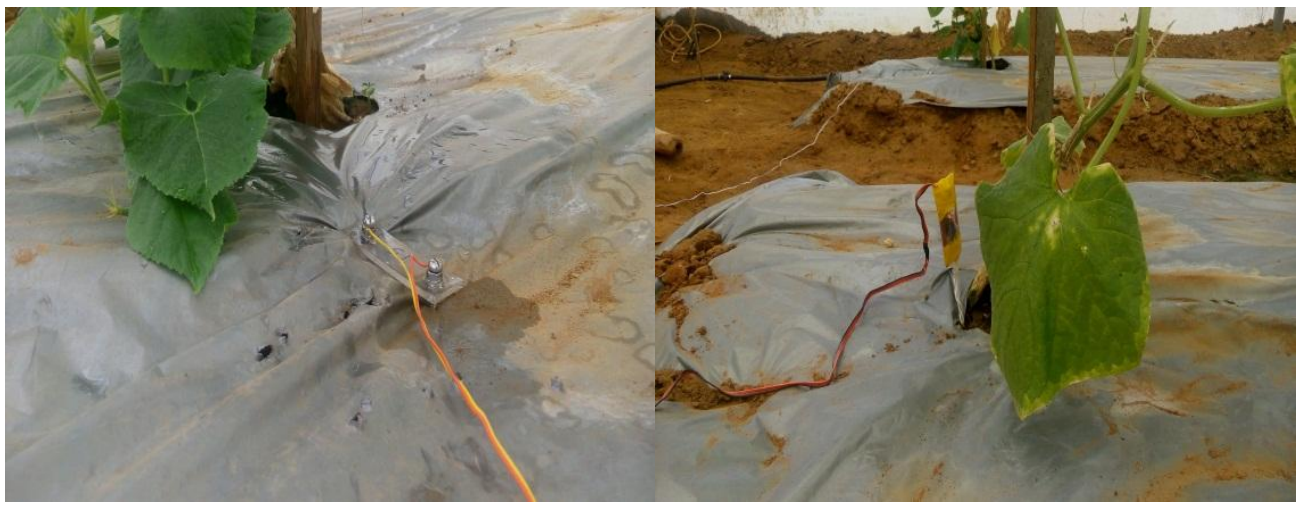

Fig.6 Experimental plot

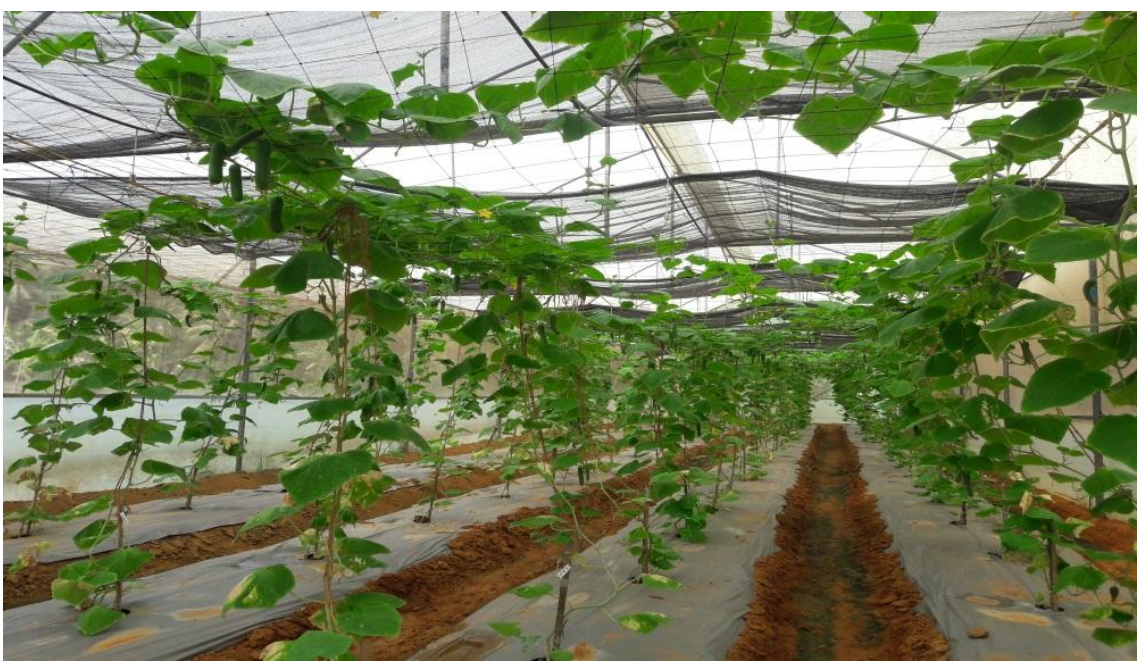


The capacitance and EC values, obtained from the calibration curve of laterite soil, corresponding to the moisture content at wilting point and field capacity were used to set the lower and upper limit of capacitor and conductive type sensors respectively. This value was $10 \mathrm{~F}$ and $42 \mathrm{~F}$ for capacitor sensor and $168 \mathrm{mS} / \mathrm{m}$ and $234 \mathrm{mS} / \mathrm{m}$ for the conductive type sensor. All the data were stored using microcontroller unit and transferred to the PC via real term software. Overall view of experimental plot is shown in the figure 6.

\section{Growth and yield parameters}

Growth parameters such as plant height, number of leaves, number of flowers and stem girth were taken 14, 21, 28, 35, 42 and 49 days after planting (DAP) and are given in table 2 to 5. Data were collected for irrigation and fertigation having two levels of operation 100 percent and 70 percent. Statistical analysis was carried out using last day (49 DAP) observations of different growth parameters (Table 6) using OPSTAT (two factor analysis) software.

Yield parameters such as number of fruits, fruit length, circumference and weight were taken at 42, 49, 56, 63, 70, 77 and 84 days after planting. The statistical analysis was carried out with last day (84 DAP) observations of different yield parameters (Table 7) using OPSTAT (two factor analysis) software.

Field experiment of salad cucumber grown using drip automation system gave 112.665 $\mathrm{kg}$ of yield in T1. Experiment showed high yield i.e. $126.535 \mathrm{~kg}$ obtained from $\mathrm{T} 2$. Lowest yield obtained was $85.635 \mathrm{~kg}$ in T3, whereas $96.835 \mathrm{~kg}$ was obtained from T4.

In conclusion the automated irrigation system consists of conductive and capacitor sensors for the soil moisture measurement and thereby we could irrigate each bed according to the requirement. This automated irrigation system could operate with GSM technology. The drip automation system and motor were operated using 'SMS' from mobile phones through GSM modem. This system is very cost effective and portable. 100 per cent fertigation showed good result compared to 70 per cent fertigation. The combination of 100 per cent fertigation and 70 per cent irrigation showed better crop performance. 70 per cent fertigation and 70 per cent irrigation treatment was showed lowest crop yield. In future the GSM modem can be modified to use in battery charging, which will help to avoid manual switching ON/OFF of modem and Photovoltaic panels can be used as the power source for the modified system. Voltage fluctuations in the board resulted in false reading while operation. As the main valve opens only at certain pressure, more pressure is needed for the solenoid valve operation. The GSM modem can operate only using electricity, thus if it is switched OFF, operator has to switch it $\mathrm{ON}$ from the control point. Entire system needs to be fully covered with a protective cover, in order to prevent from water contact.

\section{Acknowledgement}

It is a matter of deep privilege to express gratitude and indebtedness to Dr. Sajeena, S, Assistant Professor, KVK, Malappuram, for her valuable guidance and constructive criticism for doing research and in the preparation of manuscript. Words seem to be inadequate to express my sincere thanks to Dr. Hajilal M.S, Dean, KCAET, for the unfailing guidance and support that he offered while carrying out the project work. I express my heartfelt thanks to Dr. Abdhul Hakkim, V.M, Professor and Head, Dept. of LWRCE, Dr. Rema, K. P, Professor, Dept. of IDE and Er.Shivaji, K. P,Assistant Professor, Dept. of 
FPME, KCAET, Tavanur, valuable suggestions and constant backing at all stages of this research work.

It is my pleasure to offer whole hearted thanks to Principal Investigator and other staff members of precision farming and developing center for giving valuable suggestions and better environment during all stages of this research work. With great pleasure I express my heartfelt thanks to my friend Er. Lakshminarayana S.V for his support during my thesis work. Also express my deep sense of gratitude to my loving parents, family members and friends for their continuous support and inspiration all through my studies.

\section{References}

Arsoy, S. 2014. Constant energy calibration for permittivity based moisture probes. J. Hydrol., 510: 79-91.

Brevik, E.C., Fenton, T.E., and Hortan, R. 2004. Daily soil temperature fluctuations on soil electrical conductivity as measured with the geonics EM-38. Precision Agric., 5: 145-152.

Carpena, R.M., Shukla, S., and Morgan, K. 2004. Field devices for monitoring soil water content. University of Florida Cooperative Extension Service, institute of food and agricultural sciences, EDIS.

Dursun, M. and Ozden, S. 2011. A wireless application of drip irrigation automation supported by soil moisture sensors. Sci. Res. Essays, 6(7): 1573-1582.

Erlingsson, S., Baltzer, S., Baena, J., and Bjarnason, G. 2009. Measurement techniques for water flow. In: Dawson, A. (Ed.), Water In Road Structures, Springer, 5. pp. 45-67

Gunturi, V.N.R. 2013. Micro Controller Based Automatic Plant Irrigation System. Int. J. Advmt Res. Technol., 2(4).

Michael, A.M. 2008. Irrigation Theory and Practice, ( $2^{\text {nd }}$ Ed.). Vikas Publishing House PVT LTD. New Delhi. 459p.

Nagarajapandian, M., Prasanth, R.U., Kumar, S.G., and Selvan, T.S. 2015. Automatic irrigation system on sensing soil moisture content. Int. J. Innovative Res. Electr. Electr. Instrum. Control Eng., 3(1).

Prathyusha, K. and Chaitanya, S. 2012. Design of Embedded System for the automation of Drip Irrigation. Int. J. Appl. Innovation Eng. Manag., 1: 254 258.

Stangl, R., Buchan, G.D., and Loiskandl, W. 2009. Field use and calibration of a TDR-based probe for monitoring water content in ahigh-clay landslide soil in Austria. Geoderma, 150: 23-31.

Vijayakumar, G., Tamilmani, D., and Selvaraj, P.K. 2010. Irrigation and fertigation scheduling under drip irrigation in brinjal crop. Int. J. Bio Resour. Stress. Manag., 1(2): 72-76.

\section{How to cite this article:}

Arjun Prakash, K.V., S. Sajeena and Lakshminarayana, S.V. 2017. Field Level Investigation of Automated Drip Irrigation System. Int.J.Curr.Microbiol.App.Sci. 6(4): 1888-1898. doi: https://doi.org/10.20546/ijcmas.2017.604.225 